the wake of the recently bulldozed roads can afford, let alone raise, beef. But small-scale agouti farming with babassu offers the peasant a promising and inexpensive alternative. Although not as prolific as rabbits, an adult agouti weighs three kilos and the female can produce up to three litters a year averaging two offspring each. Large commercial undertakings in urban centres could profit from the ready market for cotia meat. Restaurants in Belém, for example, used to offer a variety of cotia dishes at prices equivalent to choice filet mignon. Commercial exploitation of wildlife is now outlawed in Brazil, and game farming offers the only legal alternative source of regional delicacies.

\title{
Who Cares in Hawaii?
}

\section{Jerome J. Pratt}

More than 95 per cent of Hawaii's original fauna and flora occurs nowhere else in the world. In 1965 the compiler of the Birds Red Data Book, Jack Vincent, listed 25 of Hawaii's original 69 bird species as extinct. With the discovery of a new not yet named Honeycreeper (Drepanidiae) on Maui in 1973, by a National Science Foundation sponsored expedition and the re-discovery of the Maui nukupuu Hemignathus lucidus effinus in 1967, the count changed to 70 known species with 24 extinct. Of Hawaii's remaining 46 endemic birds 27 are threatened with extinction.

At the moment the extermination of several endangered birds is being accelerated by official indifference. If it had not been for $\mathbf{M r}$ Herbert Shipman of Hilo, Hawaii, the Hawaiian goose or nene Branta sandvicensis could have become extinct because of this attitude. In 1935, the entire flock of 42 nene in the hands of the Territorial Board of Agriculture and Forestry were given to various sugar and pineapple plantation managers and territorial senators, and by 1950 only one of those 42 was known to be alive-the gander of a pair given to the Honolulu Zoo. However, Mr Shipman had maintained a few semi-wild nene on his ranch for many years: in 1949 his flock numbered eleven birds and it is from these eleven that, with time and talent furnished by aviculturists in the United States and in England (the Wildfowl Trust) the species has been perpetuated, and captive-reared birds have been returned to Hawaii and successfully established in the wild.

The Hawaiian stilt Himantopus himantopus knudseni has not been as lucky as the nene, and this beautiful bird is in extreme danger. Its habitat is being destroyed to expand facilities for tourism. The bird's most important habitat is Kanaha Pond, on the island of Maui, which, together with adjacent lands, is state-owned property under the jurisdiction of the Department of Transportation as part of the Kahului Airport. This area is not needed for airport enlargement and could become a permanent wildlife sanctuary.

To the dismay of conservationists, Kanaha Pond has been chosen 
as the site for a sewage disposal plant. There may not be more than 1000 Hawaiian stilts left in the entire island chain, and the loss of Kanaha Pond as a breeding area destroys this unique bird's main hope for survival. Moreover it has been suggested that the Fish and Game Division will monitor the area to ensure that the bird numbers do not increase, possibly by destroying nests.

Another stilt breeding area, the ponds on the Kaneohe Marine Air Station on Oahu, has been set aside by the military commander as a sanctuary for the stilts, but there is constant pressure to turn this federally owned land over to the State of Hawaii; this would quite likely mean the loss of this habitat.

If the present trend toward turning Hawaii into a massive tourist attraction is not halted there is little hope for any of the 26 bird species now threatened with extinction. It is also urgently necessary to eliminate the feral mammals that are rapidly destroying the native flora as well as those that prey directly on the endemic fauna. If the people of Hawaii become aware the world is observing the needless destruction of their paradise they may be able to change political attitudes before it is too late.

\section{Education in Costa Rica}

SEED MONEY. These two simple drawings to illustrate a food chain are reproduced from an excellent, profusely illustrated 42-page booklet $L a$ Ecologia designed for young people in Costa Rica. FPS gave $£ 500$ from the ORYX $100 \%$ Fund towards the cost of the book at the request of our Consultant, Ing. Mario A. Boza, who urged the vital necessity of getting young people interested in wildlife and conservation. The book, he writes, is being enthusiastically received and selling well at CR\$5 a copy (about US 60 cents). The profits will be used for more conservation publications. 'The FPS donation', he says, 'is truly seed money".
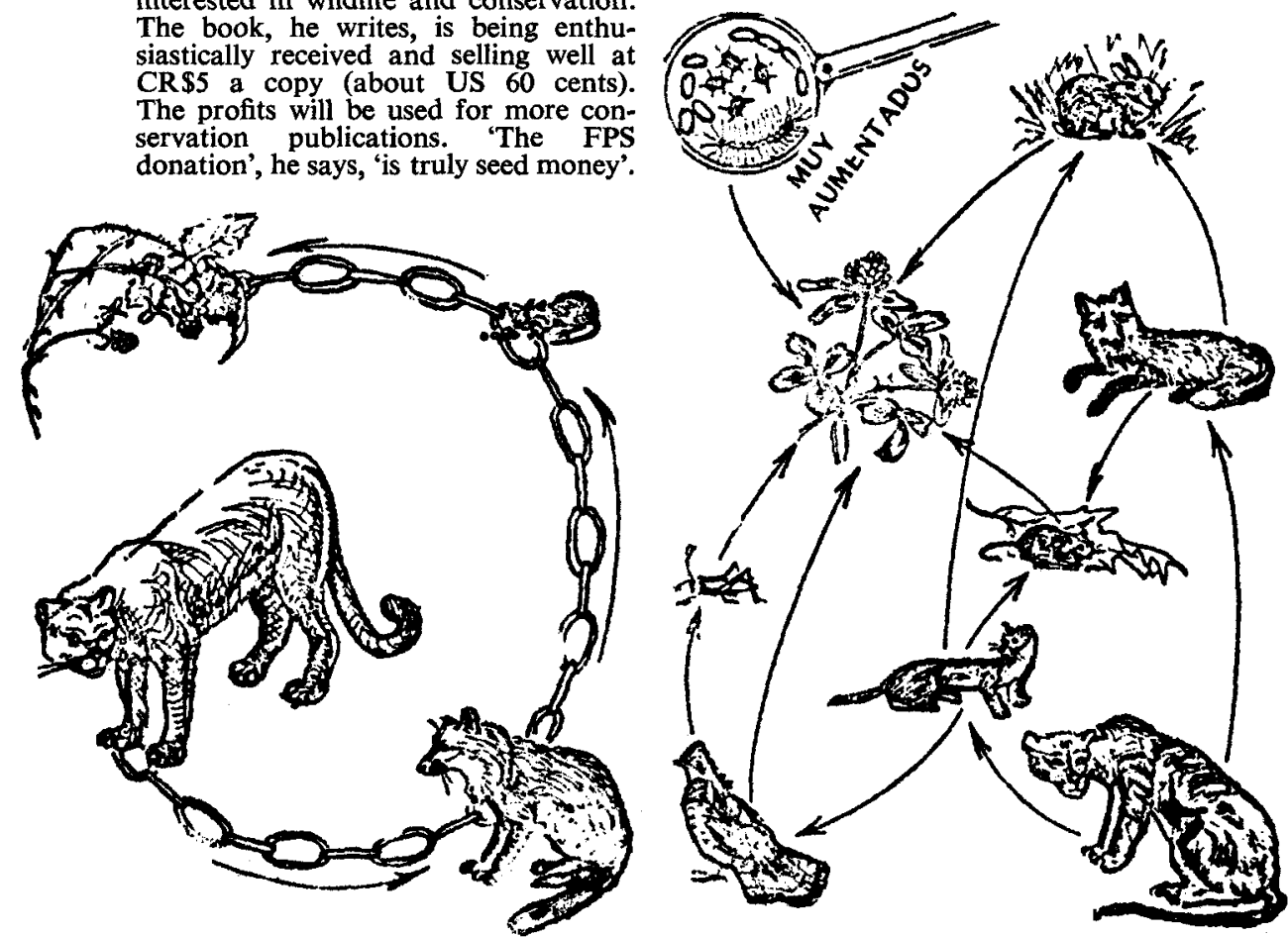